\title{
CHAPTER II
}

\section{The view from the mountains}

So far I have presented a largely external view of Toraja history, using a chronology that would be recognisable to professional historians. Against this background I shall now discuss some of the accounts of the past that Toraja people themselves told me. In some tales, a Toraja protagonist becomes the original ancestor of ruling dynasties in the lowlands, or the source of their conversion to a world religion; in others, conversely, Toraja noble families claim mythical figures of Bugis origin as prestigious founding ancestors. These stories form the means by which Toraja have positioned themselves in relation to other peoples of South Sulawesi. In different ways, they affirm the close historical relationships that have existed between highland and lowland people, while presenting a variety of claims on matters of precedence.

\section{The story of Laki Padada}

Some Toraja myths, told in relation to the founding of particular houses, serve at the same time to situate Toraja in relation to the Bugis and Makassar. Several provide grounds for claiming precedence over what were objectively the much more powerful lowland kingdoms. ${ }^{1}$ The royal families of these kingdoms, who, as I have mentioned, have links through marriage with the Toraja nobility, themselves acknowledge their links to a Toraja ancestor, Laki Padada. The Laki Padada story is a prominent one in the corpus of Toraja myth, and interestingly he is also mentioned in the Chronicle of Gowa, as well as in genealogies of Selayar (an island to the south of the peninsula), although according to Reid (1983b:129) he does not feature in any Bugis literature. I myself witnessed an acknowledgement of descent from Laki Padada

1 On precedence and its contestation in Austronesian societies, see Fox (1995) and Reuter (1992). The Sumatran accounts presented by Reuter show obvious parallels with Toraja tales and include several examples in which a younger or weaker adversary, by means of cleverness, trickery, or the possession of spiritual powers, establishes a claim to precedence over a senior or more powerful adversary. 
in the attendance, in 1983, of the elderly Datu of Luwu' and members of his family at a ceremony held to celebrate the rebuilding of a famous tongkonan, Nonongan, in Sanggalangi' district. The founder of this tongkonan is a woman, Manaek, and Laki Padada features prominently in its genealogy, along with several other mythical figures. Many origin houses in other parts of Toraja can trace a tie to this tongkonan, and more than a hundred separate groups of descendants attended the ceremony. Each brought with them a huge pig for sacrifice, trussed into a tall decorated litter (lettoan) as is customary at Toraja house ceremonies. The Datu sent a letter in advance, acknowledging that he counted himself among the descendants of Manaek (bati'na Manaek), and despite being Muslim, his party showed deference to Toraja custom in bringing a conspicuously large pig. Links with Gowa were represented at this ceremony by the presence of Puang Tandilangi' of Sangalla', who married a woman of the Gowa royal family from which he is himself descended through marriages in previous generations. Also attending were Torajans intermarried with the royal family of Bone.

Laki Padada is represented in several genealogies as a grandson of Tamboro Langi', one of Toraja's most famous to manurun. His father Puang Sanda Boro married a woman whom he discovererd inside a bamboo; she was called To Bu'tu ri Pattung ('One who Appeared from a Bamboo') or Puang Ao' Gading ('Lady of the Bamboo'). She gave birth to two children, a son, Laki Padada, and a daughter, Puang Mate Mangura or Puang Mate Malolo (both names mean 'Lady who Died Young'). Distraught at his sister's death, Laki Padada vowed to travel the world in search of the secret of eternal life. His journeys eventually brought him to the Makassarese kingdom of Gowa. ${ }^{2}$ Here after many adventures he married the ruler's daughter. Of their three children, one, Pattala Bantan, returned to Toraja and married Petimba Bulaan ('Golden Dipper'), variously depicted as the daughter or granddaughter of Manaek, founder of tongkonan Nonongan. Pattala Bantan went to Sangalla' and ruled over the Tallu Lembangna, the 'Three Domains' of Ma'kale, Sangalla', and Mengkendek, taking on the title 'Matasak ri Toraja' (matasak: literally 'ripe'; here said to have the sense of 'pure' or 'original'). A daughter, Pattala Bunga, became the ruler of Gowa, with the title 'Somba ri Gowa'; the third child, Pattala Merang, also a daughter, became the ruler of Luwu', with the title 'Payung ri Luwu' (payung: 'umbrella', an item of regalia). Later descendants of Laki Padada are said to have married into the royal family of Bone, adopting the title Manggau' ri Bone. Many versions of the story also describe the heirlooms each received from Laki Padada as their share, including

2 Published versions of the Laki Padada myth can be found in Nooy-Palm (1979:148-53) and Koubi (1982:346-58). In Nooy-Palm's version and some others, the children of Laki Padada were three sons. The version given here follows that recounted to me by Bua' Sarungallo in 1978. 
ancient textiles and swords. The sword named Sudan, or Sudanga, remained in Gowa; another, Bunga Waru, is preserved by the ruler of Luwu', while Pattala Bantan returned to Toraja with two swords, Maniang and Dosso, as well as a precious banner, the Bate Manurun. Tongkonan Kaero (founded by children of Pattala Bantan) holds the sword Maniang, which was drawn from its sheath and displayed to the crowds after the Datu of Luwu' had given a speech at the ceremony. ${ }^{3}$

Reid (1983b:130) writes that it is impossible to be sure whether the Laki Padada myth was borrowed by Toraja from Gowa (he appears not to entertain the reverse possibility), perhaps during the early seventeenth century when Makassar in its period of greatness had some influence in the highlands, or whether it might provide some more real evidence of historical contact between the two areas. Nothing more than speculation is possible on this count, though he suggests that, if so, Laki Padada with his famous swords may represent the spread of sword-smithing technology from Toraja to Gowa - an interpretation that is bolstered by other traditions among the Bugis which acknowledge Toraja as the source of metal-working techniques. In this respect at least, highlanders had the edge over the lowland kingdoms, since this technology was obviously very highly valued, and it is noticeable that many other stories also feature remarkable swords.

\section{Heroes, tricksters, and relations with lowland kingdoms}

It is difficult to establish just how far Luwu' dominated the highlands in times past. So far as I could establish, regions closest to the borders of Luwu' paid some customary tribute without, it seems, expecting any interference in their affairs; there were no officials from Luwu' posted in Toraja. Pak Ulia Salu Rapa' of Nanggala described how only those areas which had marriage links with Luwu' royalty would bring their seed rice to be blessed by the Datu at the start of the agricultural cycle, in a ritual called medatu (compare Nooy-Palm 1979:91). Bua' Sarungallo described how the Toraja annual tribute consisted of one buffalo per district, which continued to be paid until Dutch times, but others claimed only those regions closest to Luwu' paid tribute, and not always in buffaloes. In any case, Sarungallo maintained, Torajans looked

3 According to the story as told to me by Bua' Sarungallo, Laki Padada in his search for eternal life reached an island where the inhabitants promised to grant his wish if he could stay awake all night. But he slept, and after calling his name three times, they cut off the tip of his sword as he was sleeping; thus he failed in his quest for immortality. Maniang is this sword with no tip; its public display is clearly a form of proof both of the legend and of the relations of descent which were being reaffirmed by participants in the ritual. 
on it merely as an acknowledgement of their blood relations (rara buku) and respect for the fact that Luwu' had a king, which Toraja did not. Luwu' for its part also desired good relations with Toraja in order to trade for rice and forest products. ${ }^{4}$ The buffaloes would all be led together to the Datu's palace in Palopo, and surrendered to palace servants; but the representative from Kesu' was allowed to sit on his buffalo, which would be led to a special enclosure. Coming from Kesu', Bua' Sarungallo had a number of other stories to tell, most of them humorous, which established Kesu's claim to a privileged relation with Luwu', while simultaneously asserting precedence over the rival districts of Sangalla', or of Ma'kale; or which described how Kesu' had outwitted Luwu' at the same time as its local rivals. Needless to say, experts from the latter areas have their own claims to precedence. An instance can be found in a narrative published by Puang Paliwan Tandilangi' (1975:102), the point of which is to establish both a marriage relation between Luwu' and Sangalla', and the precedence of tongkonan Kaero in Sangalla' over Rano (formerly a dominant tongkonan in Ma'kale). Pelras provides more evidence for a historically close relation between Luwu' and Toraja: the Datu of Luwu' must have some Toraja blood in order to be an acceptable candidate for office, and traditionally wears a Toraja loincloth beneath his other garments at his investiture. The Puang (or Lord) of Sangalla' is always invited to such ceremonies and has the unique privilege of ordering the Datu around, while all the other nobles present must treat him (or her) with the greatest deference. ${ }^{5}$

Several popular tales recount how a Toraja 'trickster' manages to outwit the Datu of Luwu' ${ }^{6}$ The tendency of these stories is to downplay the extent of Toraja subservience to Luwu', or even to claim a degree of precedence over Luwu'. One recurring theme concerns a hero, known in variants I collected in the Kesu' area as Tali Siba'ba, whose mother is a wild pig. He weds the female Datu of Luwu' and secretly installs his mother in the attic of the palace, forbidding the local populace to eat pork out of deference to her; this is claimed to account for why the people of Luwu' (who have been Muslim since the early seventeenth century) do not eat pork. In one version, the hero ends by changing his name to Karaenge Dua ('Twice Noble'), having become a noble of Luwu' as well as Toraja. An almost identical tale concerns the sons of

4 Sago has traditionally provided an alternative staple in Luwu', while rice agriculture remained for long underdeveloped.

5 Pelras, personal communication.

6 See Volkman (1985:22) for an example. A variety of 'trickster' tales feature a hero called Dana' or Dalana'i; he is often depicted as playing outrageous tricks on fellow-villagers and even his own parents. There is a kind of continuity between these tales, the putatively historical accounts in which one area outwits more powerful rivals, and the stories that men sometimes enjoy telling about themselves, in day-to-day conversation, of how by their wits they outfaced a competitor or punctured the arrogance of a more powerful or wealthy individual. 
Bonggakaradeng, a blacksmith who has given his name to the most westerly present-day kecamatan (district) of Tana Toraja; but in this case the story concerns relations with the Bugis area of Sawitto (present-day Pinrang), which borders on West Toraja and with which the Toraja regions of Bonggakaradeng and Simbuang have historically had close connections. ${ }^{7}$ Bonggakaradeng came from a village called Batu Tandung, near the Masuppu' River. He was another person who found his wife inside a bamboo; her name was Datu Baringan, and she had a sister who was a python. Once while out in the forest on a hunting trip, Bonggakaradeng stopped to rest beneath an uru tree at a place called Pokka Uru on Buttu Karua (a mountain in Simbuang). ${ }^{8} \mathrm{He}$ urinated on a fallen tree, unaware that in doing so, he had impregnated a spirit pig inside the tree. The pig gave birth to twin boys, Buttu Karua and Buttu Layuk. When they were about six years old, the mother sent them to look for their father, and they came to where Bonggakaradeng was working in his forge. They offered to help him in the forge, but he refused, not seeing how they could be of any use to him. But while he was eating his lunch in the house, they finished all his work for him, and to a standard exceeding his own. According to another version, they made a sword of gold (la'bo' penai bulawan) called Tonapa. This sword became a famous heirloom whose sheath is still kept in Sawitto, while the blade is in Simbuang. ${ }^{9}$ Eventually they persuaded the astonished Bonggakaradeng that he was indeed their father, and lived with him for a time, but, offended by his persistence in eating pork, they set off again by boat down the Masuppu River, taking their mother with them, until they reached Sawitto, where the pig-mother eventually turned into stone. ${ }^{10}$ They made magic there, causing the sky to go dark except around their own house, until the local people begged for an explanation. The brothers told them that they would bring back the sunlight if the people would agree henceforth always to show them various marks of respect, and

7 The account given here is condensed from much longer versions of the Bonggakareng story which I collected in 1978 from Ambe' Sora of tongkonan Rea, and Indo' Lembang, the to manakka or female priest of Tondok Tanga', both in Simbuang. Another variant, given by Mappa', the elderly headman of Balepe', concerned a hero called Pokka Linoan, and demonstrated the precedence of the district known in Dutch times as Bau, over the adjoining Bugis-inhabited area of Enrekang. In this tale, one of the sons of Pokka Linoan marries a beautiful princess of Enrekang, who gives birth to Sawerigading and his twin sister (see below).

8 Uru is a kind of large hardwood tree, favoured for house timbers.

9 The sword and sheath were divided at the making of the great oath (basse kasalle) after Arung Palakka's failed invasion of Toraja in the seventeenth century. The blade is said to be kept at tongkonan Paken in Simbuang. If Bugis ever again invade Toraja, the sword can be taken out and given offerings, and when pointed directly at Sawitto and with the correct spells recited over it, will stand straight up and thus 'awaken the oath' (ma'tundan basse).

10 In the Tali Siba'ba story, it was her trough that turned to stone and is said to be still in Luwu'. 
to abstain from eating pork or the meat of any animal that died without being slaughtered. Thus the people of Sawitto became Muslim, while the two brothers married the daughters of a great aristocratic family, and had several children who became important ancestors in their turn. This is one of several tales told in justification of a saying in Simbuang: nene' Simbuang, appo Sawitto, or 'Simbuang is the grandfather and Sawitto is the grandchild'. Clearly this is an attempt to assert precedence over Sawitto, interesting because, just as in the case of Toraja-Luwu' relations, objectively Sawitto was a more powerful kingdom. According to Bigalke (1981:25), from the seventeenth to the nineteenth century Simbuang was drawn into a tributary relationship to this small state; the Dutch, however, terminated this relationship by incorporating Simbuang into the administrative subdivision of $\mathrm{Ma}^{\prime} \mathrm{kale}$, as a means of punishing Sawitto for its heavy resistance to Dutch forces.

From Saluputti comes an almost identical story, told to me by Bine' of Tombang (Menduruk), an elderly aristocratic lady, about the ancestor Kila' Ta'pa ri Ba'tang ('Lightning Striking a Tree'). He is said to have descended on top of Mount Messila in a lightning storm. In Menduruk there is a village called Bone, and this version of the story was used to explain how the Bugis Bone got its name. As in the previous version, Kila' had a child by a pig mother on Buttu Karua. The son was called Tali Tallu. Taking his pig-mother and her trough, as well as a large quantity of earth from Bone village, he travelled first to Palopo and thence to the Bugis Bone, which at that time was called Same'. Here he deposited the earth, which became Palakka (an area in the heartland of the Bone kingdom), and built himself a house on it, the steps of which are said to have turned to stone and to be still visible there today. The original Toraja Bone then became known as Bone Matua ('Old Bone'), while the Bugis region was known as Bone Malolo ('Young Bone'). Tali Tallu married the daughter of the Datu of Same', and as in the previous story, turned the sky dark for seven days and nights and made the local people give up eating pork. This story's claims are even more audacious than those of the previous one, given that Bone was at one time the most powerful of all the Bugis kingdoms.

In Sa'dan and Balusu, areas of northeast Toraja bordering on Luwu', a different story is told about an unusual hero from Sa'dan named Bulu Nanga ('Hairy Penis'). Bulu Nanga once travelled with a party of his followers and slaves to purchase buffaloes and salt in Palopo. The attendants of the Datu of Luwu' saw him bathing in the river and, catching sight of his remarkable appendage, made a report to the Datu. Bulu Nanga married the Datu's daughter, and his sword, called La Karurung, is said to be still kept in the palace at Palopo. Although these stories were no doubt told largely for local benefit, reference to myth can still be useful on occasion in interactions with lowlanders; an acquaintance recounted how on a visit to the provincial capi- 
tal of Ujung Pandang, an elderly Toraja priest (to minaa), on meeting a Bugis government official, impressed the latter by his genealogical inquiries, by means of which he quickly established that the official must be the descendant of a mythical Toraja ancestor! ${ }^{11}$

While these tales establish Bugis descent from Toraja heroes, some Toraja noble houses conversely claim descent from Bugis heroes. An example is Sawerigading, father of La Galigo, whose many adventures are recorded in the Bugis epic cycle of I La Galigo and known throughout Sulawesi. Such legitimating claims are made chiefly by the aristocracies of the districts adjoining Luwu', who have historically had, and still have, more contact with the former kingdom through intermarriage. I encountered examples both from Sa'dan and Balusu in the northeast, and from the southern federation of Ma'kale, Mengkendek and Sangalla'. Pak Banti (Papa' Mawiring), who is a descendant of tongkonan Galugu Dua in Sa'dan district, provided me with a written genealogy of 16 generations, the founding figure of which is Andi Tendriabeng (B.: Wé Tenriabeng), Sawerigading's sister, shown as having married one Ramman di Langi' of tongkonan Punti in Sesean. ${ }^{12}$ This genealogy meticulously records the names of many other tongkonan founded by the descendants of the original couple, exemplifying the importance in Toraja memory of houses as much as individuals. Five generations later, two brothers, both called Galugu (hence the present name of the settlement, Galugu Dua, meaning 'two Galugus'), are said to have been among the 'Ancestors of the Same Dream' (Nene' Pada Tindo) who 'held back the mountain of Bone' (untulak buntuna Bone), or resisted Arung Palakka's invasion of the midseventeenth century. Further south, I collected versions of the Sawerigading story from to minaa sando Tato' Dena' of Mandetek in Ma'kale, and from an elderly blind storyteller, Indo' Somba, of Kandora in Mengkendek, who was one of several informants providing detailed accounts to Salombe' (1975). Indo' Somba's version, like that published by Salombe' (1975), retains Sawerigading's origins as the grandson of Batara Guru (the mythical first ruler of Luwu', descended from heaven). Tato' Dena's, on the other hand, transposed the whole story to Toraja, explaining that Sawerigading and his

\footnotetext{
11 Certain orientations may be maintained partly through details of everyday practice. According to Bua' Sarungallo, it is, or was, a habit of the aristocracy of Kesu' not to eat bananas that grow on the side of the trunk facing toward Luwu'; they milk their buffaloes with their backs to Luwu', and won't drink palm wine if the tube it drips through points toward Luwu'. Similarly, I was told in Simbuang that the aristocracy there refuse to eat bananas that grow pointing toward Sangalla'. Both these cases represent the acting out of a separation from, or denial of claims to precedence by, a potentially more powerful adversary.

12 Other mythical figures in this genealogy include Bua Lolo', the daughter of Lambe' Susu (see Koubi 1978), and Suloara', the legendary first priest or to minaa from Sesean.
} 
twin sister had appeared from no-one knew where at Tengan (Kandora). ${ }^{13}$ Kandora seems to have established for itself a particularly strong association with Sawerigading, for a special 'house' in the form of a rice barn here at Potok Tengan contains stones, treasured as powerful heirlooms, which are said to be the petrified remains of La Pindakati of Cina, Sawerigading's first wife. ${ }^{14}$ The stones were brought here by La Pindakati's daughter Jamanlomo or Jamallomo, who married Puang Samang of Gasing (a mountain in Ma'kale district). In Salombe"s account, it is stressed that Jamallomo, being a descendant of Batara Guru, could only wed a man who was also a descendant of a to manurung or one descended from the heavens. Puang Samang, being a descendant of the Toraja to manurun Tamboro Langi' (claimed in this region to have descended on Mount Kandora), proved an acceptable suitor. Jamallomo returned with him to Toraja, where they founded tongkonan Dulang at Potok Tengan (Salombe' 1975:276-7). A notable feature of the account given by Salombe' is the naming of particular places connected to the travels and deeds of the protagonists, names which survive to the present day. A place with a large mango tree is still called Pao ('mango'), for example, while a spot where buffaloes were bathed is still called Pa'burasan ('place of foam') (Salombe' 1975:275). A local landscape is in this way given meaning in a manner familiar to us from many other societies. ${ }^{15}$

The stories told here form part of a pool of mythical narratives to which peoples throughout Sulawesi have contributed. The fact that the Sawerigading story, for instance, occurs in such an amazing number of variants all over Sulawesi, being deployed in different forms to suit local claims and purposes, is itself evidence of historical processes linking neighbouring peoples on this vast island. The tales of Toraja heroes and their supernatural abilities operate

\footnotetext{
13 Nourse (1998:135) records a similar process of 'cooptation and simultaneous denial of Bugis heritage' in the Sawerigading stories of Central Sulawesi.

14 In Salombe's version, Pindakati came from Biduk, on the slopes of Mount Latimojong; it was his second wife, Lisudai (B.: Wé Cudai) who was from Cina. This accords with Bugis versions. (It is possible that the variation is due simply to the twenty years or more that have elapsed between Salombe"s interviews and mine with the same informant.) Lack of familiarity with Bugis history and geography results in a more curious transposition: Indo' Somba was insistent that 'Cina' referred to the People's Republic of China, rather than the ancient Bugis kingdom. A similar amnesia tends to obtain in Central Sulawesi (Nourse 1998:136).

15 Interestingly, although Indo' Somba knew such a wealth of detail about the history and myths attached to the houses of Kandora, she mentioned only in passing the name of Manaek, the Datu Baine or 'Female Lord' who founded tongkonan Nonongan and who is such a prominent ancestor in the Kesu' region. She mentioned a saying to the effect that the people of Kandora also traced descent from Manaek, and that this must not be forgotten or they would be struck by lightning; but she thought Manaek was a man, and her husband, Ondo Ira, was a woman; she knew little else about them. I take this as evidence of how localised even the knowledge of local experts is about matters of genealogy and myth (see Nooy-Palm 1979:153-4).
} 
both to establish claims of precedence at home, and to depict longstanding links with more powerful neighbouring states in ways that are flattering to the Toraja sense of agency and autonomy. They provide genealogical links between the Toraja aristocracy, with their claims to descent from the sky, and the ruling nobility of Bugis and Makassarese kingdoms. But there is another story which seems to be even more deeply embedded in Toraja collective memory, a tale of treachery, violence and collective resistance. Though its thrust is more oppositional, this story has had a special salience as a potential source of Toraja identity. It is the story of the Ancestors of the Same Dream, to which I now turn. 